\title{
Mulching Tolerant Plant Straw on Cd-Contaminated Soil Surface Can Enhance Nutrient Uptake in Capsella bursa-pastoris
}

\author{
Jin Wang ${ }^{1, a}$, Jun Shi ${ }^{2, b}$, Shuting Yang ${ }^{1, c}$ and Xiulan $L v^{3, d *}$ \\ ${ }^{1}$ College of Horticulture, Sichuan Agricultural University, Chengdu, Sichuan, China \\ ${ }^{2}$ Mianyang Academy of Agricultural Sciences, Mianyang, Sichuan, China \\ ${ }^{3}$ Institute of Pomology and Olericulture, Sichuan Agricultural University, Chengdu, Sichuan, China

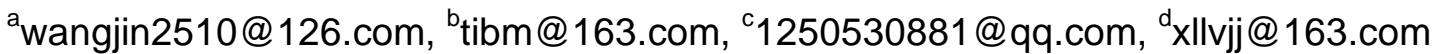 \\ ${ }^{*}$ Corresponding author
}

Keywords: Tolerant plant straw; Cadmium contamination; Capsella bursa-pastoris; Nutrient; Soil enzyme activity

Abstract. The effects of tolerant plants (Ranunculus sieboldii, Mazus japonicus, Clinopodium confine and Plantago asiatica) straws on nutrient uptake in Cd-accumulator Capsella bursa-pastoris were investigated through pot experiment under $\mathrm{Cd}$-contaminated soil condition. Five treatments were used in the experiment: not mulched with straw (control), mulched with $R$. sieboldii straw, mulched with $M$. japonicus straw, mulched with $C$. confine straw, and mulched with $P$. asiatica straw. Mulching with four tolerant plant species straws on Cd-contaminated soil surface increased phosphorus $(\mathrm{P})$ and potassium $(\mathrm{K})$ contents in roots and shoots of $C$. bursa-pastoris compared with control. The $\mathrm{P}$ and $\mathrm{K}$ contents in plants were ranked as $P$. asiatica straw $>C$. confine straw $>M$. japonicus straw $>R$. sieboldii straw $>$ control. The soil available $\mathrm{P}$ and $\mathrm{K}$ contents were increased by tolerant plant straw, which were ranked as: $P$. asiatica straw $>C$. confine straw $>M$. japonicus straw $>R$. sieboldii straw $>$ control. Mulching with four tolerant plant species straws also enhanced soil sucrase, urease and catalase activities. Therefore, Mulching with tolerant plant straw could used to increase nutrient content and enhance soil enzyme activity in $C$. bursa-pastoris for the phytoremediation of $\mathrm{Cd}$, and the $P$. asiatica straw was the best.

\section{Introduction}

In agricultural production, mulching straw on soil surface is a commonly used technique. Mulching straw can increase the organic matter and other nutrients that from plant straw [1]. So, mulching straw promotes crop plant growth, and improves yield and quality of crop plant [2]. When the straw decays and decomposes, the nutrient in the straw would be released into soil, which can affect soil nutrient availability, soil enzyme activity, microbial population structure, and plant growth [3]. If plant straw was applied to heavy metal-contaminated soil, the straw may regulate hyperaccumulator or accumulator growth and heavy metal accumulation.

Ranunculus sieboldii, Mazus japonicus, Clinopodium confine and Plantago asiatica are Cd-tolerant plants [4]. In this study, we grew seedlings of the Cd-accumulator Capsella bursa-pastoris [5] in Cd-contaminated soil. Shoots of the above-mentioned Cd-tolerant species were applied as mulches on the soil surface to screen their efficiency at promoting the nutrient uptake and soil enzyme activity of $C$. bursa-pastoris, and to provide reference for improvement in the phytoremediation ability of C. bursa-pastoris.

\section{Materials and Methods}

Materials. The shoots of Ranunculus sieboldii, Mazus japonicus, Clinopodium confine and Plantago asiatica were collected from the Ya' an campus farm of the Sichuan Agricultural University (29 59' N, $\left.102^{\circ} 59^{\prime} \mathrm{E}\right)$, China, in August 2013, at sites where the soil was not contaminated by heavy metals. The shoots were dried at $80^{\circ} \mathrm{C}$ to constant weight, then finely ground and sieved through a 5-mm-mesh 
nylon sieve. Capsella bursa-pastoris seedlings with two euphyllas were collected from the Ya'an campus farm at a site not contaminated by heavy metals in September 2013. The inceptisol soil samples were collected from Ya'an campus farm in August 2013. The basic properties of the soil were the same as reference [4].

Experimental Design. The experiment was conducted at the Ya'an campus farm in August-October 2013. The soil samples were air-dried and passed through a 5-mm sieve in August 2013 , and then $4.0 \mathrm{~kg}$ of the air-dried soil was weighed into each polyethylene pot $(15 \mathrm{~cm}$ high, $18 \mathrm{~cm}$ diameter). Cadmium was added to the soil samples as $\mathrm{CdCl}_{2} \cdot 2.5 \mathrm{H}_{2} \mathrm{O}$ at $10 \mathrm{mg} / \mathrm{kg}$. The pots were soaked in the $\mathrm{Cd}$ solution for 4 weeks, and then the soil in each pot was mixed thoroughly. Five uniform seedlings of $C$. bursa-pastoris were transplanted into each pot, and $6 \mathrm{~g}$ shoots of four Cd-tolerant species were applied as mulches on the soil surface in each pot (equivalent to $225 \mathrm{~g} / \mathrm{m}^{2}$ ). Five treatments were applied: not mulched with straw (control), mulched with $R$. sieboldii straw, mulched with $M$. japonicus straw, mulched with $C$. confine straw, and mulched with $P$. asiatica straw. Each treatment was repeated three times with a completely randomized design with $10-\mathrm{cm}$ spacing between pots. The soil moisture was maintained at $80 \%$ of field capacity from when the $C$. bursa-pastoris plants were transplanted until the plants were harvested. At maturity (after $35 \mathrm{~d}$ ), the entire plants were harvested for determining contents of total $\mathrm{P}$ and $\mathrm{K}$ in roots and shoots [6]. The soil samples were collected for determining soil available P and K contents [6] and soil enzyme activity [7].

\section{Results and Discussion}

Total $\mathbf{P}$ content in roots of $\boldsymbol{C}$. bursa-pastoris. Mulching with four tolerant plant species straws on Cd-contaminated soil surface increased the total $\mathrm{P}$ content in roots of $C$. bursa-pastoris (Fig. 1), which was consistent with other studies, because the $\mathrm{P}$ content was quite different in different plant species [3]. The total $\mathrm{P}$ content in roots of $C$. bursa-pastoris was ranked as: $P$. asiatica straw $>C$. confine straw $>M$. japonicus straw $>R$. sieboldii straw $>$ control. Compared with control, mulching with straws of $R$. sieboldii, $M$. japonicus, $C$. confine and $P$. asiatica increased the total $\mathrm{P}$ contents in roots of C. bursa-pastoris by $27.62 \%(p<0.05), 31.07 \%(p<0.05), 42.96 \%(p<0.05)$ and $54.43 \%(p<$ $0.05)$ respectively.

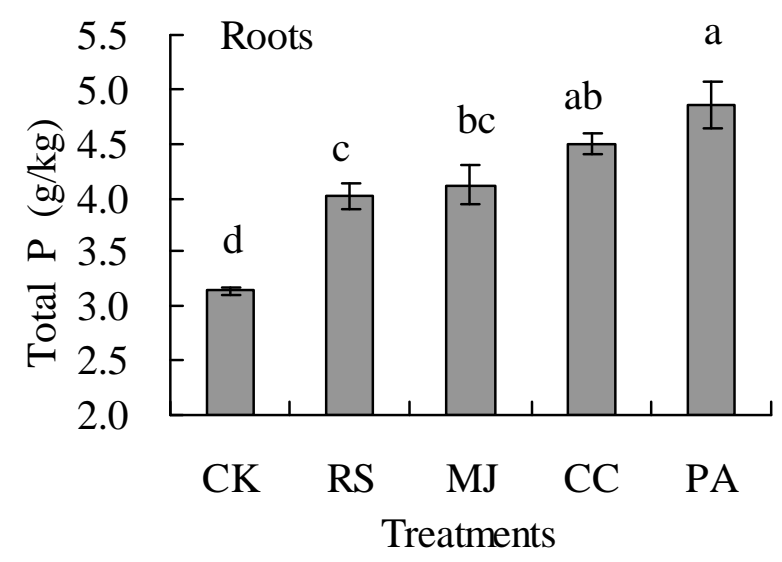

Fig. 1 Total $\mathrm{P}$ in roots of C. bursa-pastoris. Values are means of three replicate pots. Different lowercase letters indicate significant differences based on one-way analysis of variance in SPSS 13.0 followed by the least significant difference test $(p<0.05)$. $\mathrm{CK}=$ control, $\mathrm{RS}=R$. sieboldii, $\mathrm{MJ}=M$. japonicus, $\mathrm{CC}=C$. confine, $\mathrm{PA}=P$. asiatica .

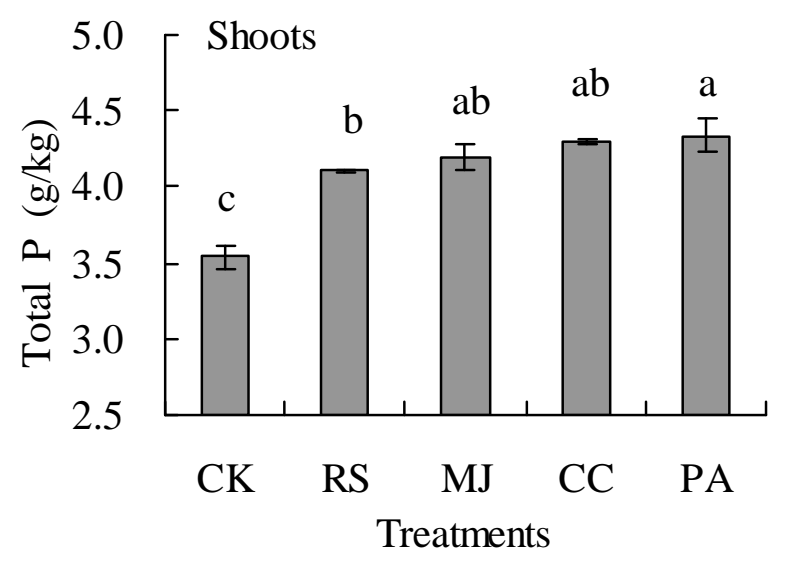

Fig. 2 Total $\mathrm{P}$ in shoots of C. bursa-pastoris. Values are means of three replicate pots. Different lowercase letters indicate significant differences based on one-way analysis of variance in SPSS 13.0 followed by the least significant difference test $(p<0.05)$. $\mathrm{CK}=$ control, $\mathrm{RS}=R$. sieboldii, $\mathrm{MJ}=M$. japonicus, $\mathrm{CC}=C$. confine, $\mathrm{PA}=P$. asiatica . 
Total $P$ content in shoots of $C$. bursa-pastoris. Mulching with four tolerant plant species straws on Cd-contaminated soil surface increased the total $\mathrm{P}$ content in shoots of C. bursa-pastoris (Fig. 2), which was the same as the total P content in roots of $C$. bursa-pastoris. The total P content in shoots of $C$. bursa-pastoris was also ranked as: $P$. asiatica straw $>C$. confine straw $>M$. japonicus straw $>R$. sieboldii straw > control. Compared with control, mulching with straws of R. sieboldii, M. japonicus, $C$. confine and $P$. asiatica increased the total P contents in shoots of $C$. bursa-pastoris by $16.09 \%(p<$ $0.05), 18.69 \%(p<0.05), 21.51 \%(p<0.05)$ and $22.72 \%(p<0.05)$ respectively.

Total $\mathrm{K}$ content in roots of $\boldsymbol{C}$. bursa-pastoris. Mulching with four tolerant plant species straws on Cd-contaminated soil surface also increased the total $\mathrm{K}$ content in roots of $C$. bursa-pastoris (Fig. 3), which was consistent with other studies [3]. The total K content in roots of C. bursa-pastoris was ranked as: $P$. asiatica straw $>C$. confine straw $>M$. japonicus straw $>R$. sieboldii straw $>$ control. Compared with control, mulching with straws of $R$. sieboldii, $M$. japonicus, $C$. confine and $P$. asiatica increased the total $\mathrm{K}$ contents in roots of $C$. bursa-pastoris by $27.40 \%(p<0.05), 48.93 \%(p<0.05)$, $58.91 \%(p<0.05)$ and $74.82 \%(p<0.05)$ respectively.

Total K content in shoots of $\boldsymbol{C}$. bursa-pastoris. Mulching with four tolerant plant species straws on Cd-contaminated soil surface increased the total $\mathrm{K}$ content in shoots of C. bursa-pastoris (Fig. 4), which was the same as the total $\mathrm{K}$ content in roots of $C$. bursa-pastoris. The total $\mathrm{K}$ content in shoots of $C$. bursa-pastoris was also ranked as: $P$. asiatica straw $>C$. confine straw $>M$. japonicus straw $>$ $R$. sieboldii straw > control. Compared with control, mulching with straws of $R$. sieboldii, $M$. japonicus, $C$. confine and $P$. asiatica increased the total $\mathrm{K}$ contents in shoots of $C$. bursa-pastoris by $11.69 \%(p<0.05), 18.88 \%(p<0.05), 39.78 \%(p<0.05)$ and $42.92 \%(p<0.05)$ respectively. So, mulching with tolerant plant straw on Cd-contaminated soil surface could efficiency increase K uptake in shoots of $C$. bursa-pastoris, and the P. asiatica straw was the best. Because the plant straw contains many nutrients (includes $\mathrm{P}$ and $\mathrm{K}$ ), which are released during the process of straw decay and decomposition and can be absorbed by living plants [8].

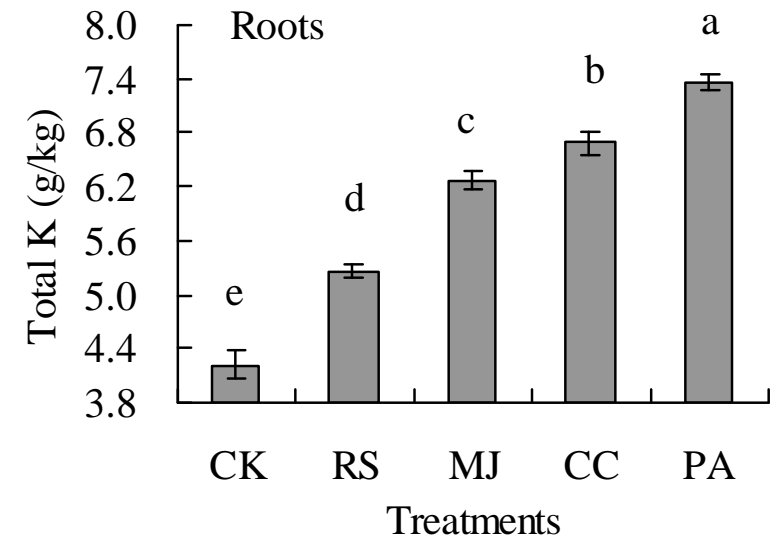

Fig. 3 Total $\mathrm{K}$ in roots of C. bursa-pastoris. Values are means of three replicate pots. Different lowercase letters indicate significant differences based on one-way analysis of variance in SPSS 13.0 followed by the least significant difference test $(p<0.05)$. $\mathrm{CK}=$ control, $\mathrm{RS}=R$. sieboldii, $\mathrm{MJ}=$ M. japonicus, $\mathrm{CC}=C$. confine, $\mathrm{PA}=P$. asiatica .

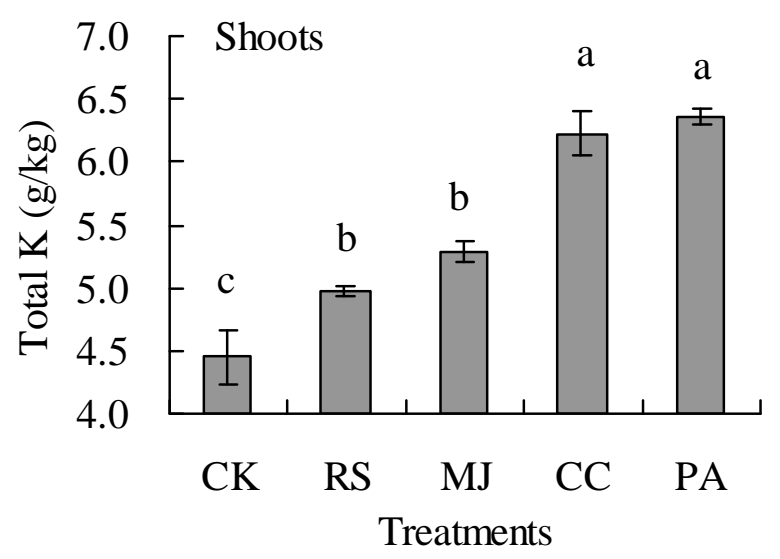

Fig. 4 Total $\mathrm{K}$ in shoots of C. bursa-pastoris. Values are means of three replicate pots. Different lowercase letters indicate significant differences based on one-way analysis of variance in SPSS 13.0 followed by the least significant difference test $(p<0.05)$. $\mathrm{CK}=$ control, $\mathrm{RS}=R$. sieboldii, $\mathrm{MJ}=M$. japonicus, $\mathrm{CC}=C$. confine, $\mathrm{PA}=P$. asiatica . 
Soil available $\mathbf{P}$ and $K$ contents. The soil available $P$ content was increased by mulching with four tolerant plant species straws (Table 1). The soil available $\mathrm{P}$ content was ranked as: $P$. asiatica straw > C. confine straw $>M$. japonicus straw $>R$. sieboldii straw $>$ control. Compared with control, mulching with straws of $R$. sieboldii, $M$. japonicus, $C$. confine and $P$. asiatica increased the soil available P content by $12.10 \%(p<0.05), 30.34 \%(p<0.05), 21.85 \%(p<0.05)$ and $30.61 \%(p<0.05)$ respectively. The soil available $\mathrm{K}$ content was also increased by mulching with four tolerant plant species straws (Table 1). The soil available $\mathrm{K}$ content was ranked as: $P$. asiatica straw $>C$. confine straw $>M$. japonicus straw $>R$. sieboldii straw $>$ control. Compared with control, mulching with straws of $R$. sieboldii, $M$. japonicus, $C$. confine and $P$. asiatica increased the soil available $\mathrm{K}$ content by $2.61 \%(p>0.05), 5.23 \%(p<0.05), 6.74 \%(p<0.05)$ and $8.01 \%(p<0.05)$ respectively. The increase rate of soil available $\mathrm{K}$ content was higher than soil available $\mathrm{P}$ content.

Soil enzyme activity. Mulching with four tolerant plant species straws on Cd-contaminated soil surface increased soil enzyme activity (Table 1), which was consistent with other studies [3]. The soil sucrase activity was ranked as: $C$. confine straw $>P$. asiatica straw $>M$. japonicus straw $>R$. sieboldii straw $>$ control, soil urease activity was $C$. confine straw $>M$. japonicus straw $>P$. asiatica straw $>R$. sieboldii straw $>$ control, and soil catalase activity was $C$. confine straw $>M$. japonicus straw $>R$. sieboldii straw $>$ P. asiatica straw $>$ control. These results could be related to the different characteristics of soil enzyme.

Table 1 Soil available $\mathrm{P}$ and $\mathrm{K}$ contents and soil enzyme activity

\begin{tabular}{|l|c|c|c|c|c|}
\hline \multicolumn{1}{|c|}{ Treatments } & $\begin{array}{c}\text { Soil available } \\
\text { phosphorus } \\
(\mathrm{mg} / \mathrm{kg})\end{array}$ & $\begin{array}{c}\text { Soil available } \\
\text { potassium } \\
(\mathrm{mg} / \mathrm{kg})\end{array}$ & $\begin{array}{c}\text { Soil sucrase } \\
\text { activity } \\
(\mathrm{mg} / \mathrm{g})\end{array}$ & $\begin{array}{c}\text { Soil urease } \\
\text { activity } \\
(\mathrm{mg} / \mathrm{g})\end{array}$ & $\begin{array}{c}\text { Soil catalase } \\
\text { activity } \\
(\mathrm{ml} / \mathrm{g})\end{array}$ \\
\hline Control & $2.901 \pm 0.042 \mathrm{~d}$ & $113.04 \pm 1.47 \mathrm{c}$ & $0.164 \pm 0.005 \mathrm{~b}$ & $0.308 \pm 0.008 \mathrm{~b}$ & $0.174 \pm 0.011 \mathrm{c}$ \\
\hline R. sieboldii & $3.252 \pm 0.073 \mathrm{c}$ & $115.99 \pm 1.40 \mathrm{bc}$ & $0.178 \pm 0.010 \mathrm{~b}$ & $0.317 \pm 0.013 \mathrm{~b}$ & $0.259 \pm 0.006 \mathrm{~b}$ \\
\hline M. japonicus & $3.491 \pm 0.011 \mathrm{~b}$ & $118.95 \pm 1.34 \mathrm{ab}$ & $0.221 \pm 0.009 \mathrm{a}$ & $0.415 \pm 0.011 \mathrm{a}$ & $0.263 \pm 0.010 \mathrm{~b}$ \\
\hline C. confine & $3.535 \pm 0.012 \mathrm{~b}$ & $120.66 \pm 0.48 \mathrm{a}$ & $0.240 \pm 0.013 \mathrm{a}$ & $0.433 \pm 0.014 \mathrm{a}$ & $0.306 \pm 0.014 \mathrm{a}$ \\
\hline P. asiatica & $3.789 \pm 0.048 \mathrm{a}$ & $122.09 \pm 1.29 \mathrm{a}$ & $0.232 \pm 0.011 \mathrm{a}$ & $0.323 \pm 0.007 \mathrm{~b}$ & $0.245 \pm 0.006 \mathrm{~b}$ \\
\hline
\end{tabular}

Values are means of three replicate pots. Different lowercase letters indicate significant differences based on one-way analysis of variance in SPSS 13.0 followed by the least significant difference test $(p<0.05)$.

\section{Conclusions}

Mulching with four tolerant plants (Ranunculus sieboldii, Mazus japonicus, Clinopodium confine and Plantago asiatica) straws on Cd-contaminated soil surface increased $\mathrm{P}$ and $\mathrm{K}$ contents in roots and shoots of Capsella bursa-pastoris compared with control. The $\mathrm{P}$ and $\mathrm{K}$ contents in plants were ranked as $P$. asiatica straw $>C$. confine straw $>M$. japonicus straw $>R$. sieboldii straw $>$ control. The soil available $\mathrm{P}$ and $\mathrm{K}$ contents were increased by tolerant plant straw, which were ranked as: $P$. asiatica straw $>C$. confine straw $>M$. japonicus straw $>R$. sieboldii straw $>$ control. Mulching with four tolerant plant species straws enhanced soil sucrase, urease and catalase activities.

\section{References}

[1] H. Zhu, J. Wu, D. Huang, Q. Zhu, S. Liu, Y. Su, W. Wei, J.K. Syers and Y. Li: Plant and Soil Vol. 331 (2010), p. 427.

[2] P.J.A. van Asten, P.M. van Bodegom, L.M. Mulder and M.J. Kropff: Nutr. Cycl. Agroecosys. Vol. 72 (2005), p. 255.

[3] F.A. Einhellig: Agronomy Journal 88 (1996), p. 886. 
[4] L. Lin, Q. Jin, Y. Liu, B. Ning, M. Liao and L. Luo: Environ. Toxicol. Chem. Vol. 33 (2014), p. 2422.

[5] Y. Liu, L. Lin, Q. Jin and X. Zhu: Environmental Progress \& Sustainable Energy Vol. 34 (2015), p. 663.

[6] S.D. Bao: Agrochemical Soil Analysis ( $3^{\text {rd }}$ edition, China Agriculture Press, Beijing 2000).

[7] L.K. Zhou: Soil Enzymology (Science Press, Beijing 1987).

[8] A. Whitbread, G. Blair, Y. Konboon, R. Lefroy and K. Naklang: Agr. Ecosyst. Environ. Vol. 100 (2003), p. 251. 